\title{
Neoplastic Plasma Cells 20 Percent or More of Peripheral Blood White Cells
}

National Cancer Institute

\section{Source}

National Cancer Institute. Neoplastic Plasma Cells 20 Percent or More of Peripheral

Blood White Cells. NCI Thesaurus. Code C158056.

A semi-quantitative microscopic finding indicating that at least 20 percent of the nucleated cells in a peripheral leukocyte sample are neoplastic plasma cells. 